\title{
THE RELATIONSHIP BETWEEN MATHEMATICS SELF-EFFICACY
}

\section{AND ACHIEVEMENT IN MATHEMATICS}

\section{T. KOMALAVALLI}

Assistant Professor, School of Education, VISTAS, Pallavaram, Chennai, Tamil Nadu, India

\begin{abstract}
The objective of the paper is to examine the relationship between Mathematics Self-Efficacy and Achievement in Mathematics of higher secondary students. A total sample of 800higher secondary Plus One students (400boys and 400 girls) were randomly selected for the study. Normative survey method was employed for data collection. The Mathematics Self-efficacy Scale was adapted from S. L. Tait-McCutcheon (2008) and modified by the investigator to suit the Indian Context and to the level of selected samples of this study. Three research questions were framed to guide this study. Results revealed that there is a significant relationship between Mathematics Self-efficacy and achievement in Mathematics. Also, there is a significant difference between boys and girls in Mathematics self-efficacy and achievement in Mathematics where girls excelled boys. Findings showed that Government Aided school students were high in Mathematics self-efficacy and achievement in Mathematics when compared to Government school students.

KEYWORDS: Mathematics Self-Efficacy, Achievement in Mathematics, Higher Secondary Students, Government \& Government Aided Schools
\end{abstract}

Received: Mar 01, 2019; Accepted: Mar 21, 2019; Published: Apr 10, 2019; Paper Id.: IJEEFUSJUN20191

\section{INTRODUCTION}

Self-efficacy research evolved from the works of Albert Bandura (1977), who theorized that one's belief about their capabilities are strongly related to the way they behave and learn. According to Bandura's Social Cognitive Theory (1997), self-efficacy has an important role in students' achievement. Self-efficacy influences students' motivation, the efforts they are willing to exert and the degree to which one may persist when carrying out tasks successfully.

A substantial body of research shows the predictive value of self-efficacy beliefs and students' academic achievement across all areas and levels and students' career choices (Brown and Lent, 2006; Pajares, 1996). According to this research, students who are more confident in their capabilities tend to work harder, solve problems more efficiently, monitor their progress regularly, and achieve better than their able peers who do not have high self-efficacy. Students with a strong sense of self-efficacy are more likely to challenge themselves with difficult tasks and be intrinsically motivated. Self-efficacy beliefs are strongly related to students' learning and achievement and teachers have the potential to greatly influence these beliefs on students.

The relationship between self-efficacy and Mathematics achievement has been well documented in the literature. For example, Langenfield and Pajares (1993) reported a significant correlation between Mathematics self-efficacy and Mathematics performance of American undergraduate students. In another similar study, Pajares and Kranzler (1995) reported that American High school students (grades 9 through 12) Mathematics self-efficacy 
had a direct impact on Mathematics performance. In addition, Mathematics self-efficacy of gifted and regular eighth grade students from the U.S.A. was investigated. The findings confirmed that Mathematics self-efficacy was a significant contributor in predicting their Mathematics performance (Pajares, 1996). The findings of the study conducted by Ayotola and Adedeji (2009) revealed that there was a significant and positive relationship between Mathematics Self-Efficacy and achievement in Mathematics.

Individuals develop self-efficacy beliefs from four underlying sources: mastery performance, vicarious experiences, verbal persuasion and emotional and physiological states (Bandura, 1997). Self-efficacy impacts on a learner's potential to succeed. An insight into how their learners feel, think, and act, about and towards Mathematics is to examine their psychological domains of functioning: the affective, the cognitive and the conative (Huitt, 1996; Tallon, 1997). Affect is a student's internal belief system (Fennema, 1989). The affective domain includes students' beliefs about themselves and their capacity to learn Mathematics; their self-esteem and their perceived status as learners; their beliefs about the nature of mathematical understanding; and their potential to succeed in the subject (Tanner \& Jones, 2003).

The cognitive domain considers students' awareness of their own mathematical knowledge; their strengths and weaknesses; their abstraction and rectification of processes; and their development of links between aspects of the subject. Cognition refers to the process of coming to know and understand, the process of storing, processing, and retrieving information. The cognitive factor describes thinking processes and the use of knowledge, such as, associating, reasoning or evaluating.

Conation refers to the act of striving, of focusing attention and energy, and purposeful actions. Conation is about staying power, and survival. The conative domain includes students' intentions and dispositions to learn, their approach to monitoring their own learning and to self-assessment.

Students with a strong sense of efficacy are more likely to challenge themselves with difficult tasks and be intrinsically motivated. Self-efficacious students recover quickly from setbacks, and ultimately are likely to achieve their personal goals. Students with low self-efficacy, on the other hand, believe they cannot be successful and thus are less likely to make a concerted, extended effort and may consider challenging tasks as treats that are to be avoided. Thus, students with poor self-efficacy have low aspirations which may result in disappointing academic performances. Self-efficacy predicts intellectual performance better than skills alone, and it directly influences academic performance through cognition.

The purpose of this study is to examine the relationship between Mathematics self-efficacy and achievement in Mathematics among higher secondary students.

\section{STATEMENT OF THE PROBLEM}

The problem of this study is to determine the relationship between students' Mathematics self-efficacy and achievement in Mathematics.

\section{RESEARCH QUESTIONS}

The following research questions have been formulated to guide this study.

- Is there any significant relationship between students' Mathematics self-efficacy and achievement in

Mathematics? 
- Is there any significant difference between boys and girls in Mathematics self-efficacy and achievement in Mathematics?

- Is there any significant difference between Government and Government Aided school students in Mathematics self-efficacy and achievement in Mathematics?

\section{METHODOLOGY}

The subjects for the study were drawn from 10 selected higher secondary schools within Chennai of Tamil Nadu State. Stratified random sampling was used in the selection of the schools. The sample comprised of students from Government and Government aided schools. In all, a total of 800higher secondary Plus One students (400boys and 400 girls) were randomly selected for the study. The target population for this study were the students in Plus One higher secondary. This category of students were selected on the assumption that they were matured enough to form independent opinion about Mathematics self-efficacy, their confidence towards the subject and their achievement in it.

\section{INSTRUMENTATION}

The investigator required an assessment of how confident the students are in solving Mathematics problems. Hence, the variable Mathematics Self-efficacy was included in the study. The Mathematics Self-efficacy Scale was adapted from S. L. Tait-McCutcheon, Victoria University of Wellington and modified by the investigator to suit the Indian Context and to the level of selected samples of this study. Statements were based on three domains namely affective, cognitive and conative. The tool comprises a total of 35 statements where affective domain consists of 12 statements, cognitive domain consists of 12 statements and conative domain consists of 11 statements. The subjects were expected to elicit their responses on a 5 point Likert type Scale ranging from "Strongly Agree" to "Strongly Disagree". In this tool, 28 items were positive questions and 7 items were negative questions. Categories of both positive and negative questions are well mixed to reduce the halo effect and logical error and also double barreled questions are avoided. The Mathematics achievement test was constructed by the investigator.

The Cronbach's alpha coefficients of the two scales were 0.81 and 0.71 respectively. On the basis of the magnitude of these indices the instrument were found to be adequate for testing purposes and were subsequently group administered by the investigator. With the assistance of the class teachers, the completed questionnaires and tests were collected from the subjects and scored accordingly.

\section{OPERATIONAL DEFINITION}

In the present study, Self-efficacy in Mathematics indicates students' self-belief in their ability to overcome difficulties or obstacles to solving Mathematics problems. Such a belief has been shown to be important to motivation because confidence that one will be able to solve a problem is a precursor to investing the time and effort needed to tackle it.

\section{DATA ANALYSIS}

Data from the study were subjected to appropriate statistical analysis to be able to draw up inferences from it. The t-test and Pearson Product Moment correlation coefficient were used for data analyses. 


\section{ANSWERS TO RESEARCH QUESTIONS}

Research Question 1: Is there any significant relationship between students' Mathematics self-efficacy and achievement in Mathematics?

Table 1: Showing the Relationship between Mathematics Self-Efficacy and Achievement in Mathematics

\begin{tabular}{|l|c|c|}
\hline & $\begin{array}{c}\text { Mathematics } \\
\text { Self-efficacy }\end{array}$ & $\begin{array}{c}\text { Achievement in } \\
\text { Mathematics }\end{array}$ \\
\hline $\begin{array}{l}\text { Mathematics } \\
\text { Self-efficacy }\end{array}$ & 1 & $0.559^{* *}$ \\
\hline $\begin{array}{l}\text { Achievement in } \\
\text { Mathematics }\end{array}$ & - & 1 \\
\hline
\end{tabular}

** Correlation is significant at 0.01 level.

The above table value shows that there is a significant and positive relationship between students' Mathematics self-efficacy and achievement in Mathematics.

Research Question 2: Is there any significant difference between boys and girls in Mathematics self-efficacy and achievement in Mathematics?

Table 2: Showing the Mean Difference between Boys and Girls in Mathematics Self-Efficacy and Achievement in Mathematics

\begin{tabular}{|c|c|c|c|c|c|c|}
\hline \multirow{3}{*}{ Variables } & \multicolumn{4}{|c|}{ Gender } & \multirow{3}{*}{ t value } & \multirow{3}{*}{$P$ value } \\
\hline & \multicolumn{2}{|c|}{ Boys $(\mathrm{N}=400)$} & \multicolumn{2}{|c|}{ Girls $(N=400)$} & & \\
\hline & Mean & SD & Mean & SD & & \\
\hline $\begin{array}{l}\text { Mathematics } \\
\text { Self-efficacy }\end{array}$ & 127.86 & 14.86 & 135.52 & 15.76 & 7.071 & $<0.001 * *$ \\
\hline $\begin{array}{l}\text { Achievement in } \\
\text { Mathematics }\end{array}$ & 42.62 & 14.50 & 47.35 & 15.99 & 4.388 & $<0.001 * *$ \\
\hline
\end{tabular}

Note: ** Denotes significant at 0.01 level.

It is inferred from the above table that there is a significant difference between boys and girls in Mathematics Self-efficacy and achievement in Mathematics at 0.01 level. From the mean scores, it is observed that girls (135.52) have more self-efficacy and high scores in Mathematics (47.35) than boys (127.86, 42.62). This may be due to the fact that girls tend to put more effort in achieving their goals and hardworking than boys. Also, they put the blame for failure on themselves like lack of effort and hard work.

Research Question 3: Is there any significant difference between Government and Government Aided school students in Mathematics self-efficacy and achievement in Mathematics?

Table 3: Showing the Mean Difference between Government and Government Aided School Students in Mathematics Self-Efficacy and Achievement in Mathematics

\begin{tabular}{|c|c|c|c|c|c|c|}
\hline & \multicolumn{4}{|c|}{ Type of Management } & \multirow{3}{*}{ t value } & \multirow{3}{*}{$P$ value } \\
\hline & \multicolumn{2}{|c|}{ Government Aided } & \multicolumn{2}{|c|}{ Government } & & \\
\hline & Mean & SD & Mean & SD & & \\
\hline $\begin{array}{l}\text { Mathematics } \\
\text { Self-efficacy }\end{array}$ & 134.54 & 14.53 & 128.84 & 16.47 & 5.185 & $<0.001 * *$ \\
\hline $\begin{array}{l}\text { Achievement in } \\
\text { Mathematics }\end{array}$ & 47.14 & 15.25 & 42.84 & 15.34 & 3.977 & $<0.001 * *$ \\
\hline
\end{tabular}

Note: ** Denotes significant at 0.01 level. 
It is inferred from the above table that there is a significant difference between Government and Government Aided school students in Mathematics Self-efficacy and achievement in Mathematics at 0.01 level. From the mean scores, it is observed that Government Aided students (134.54) have more self-efficacy and high achievement scores (47.14) than boys $(128.84,42.84)$. This may be due to the fact that Government Aided schools are under the control of Management and they provide necessary infrastructural facilities as well as well qualified staff and also conduct remedial teaching sessions for the betterment of students when compared to Government schools.

\section{EDUCATIONAL IMPLICATIONS}

From the above results, it is concluded that Mathematics Self-efficacy a significant role in enhancing achievement in Mathematics. Hence, it becomes imperative to foster self-efficacy among students in the following ways.

- Teachers can use moderately difficult tasks which are slightly above the students' current ability level.

- Concepts can be taught according to the needs and interests of the students.

- Students can be allowed to make their own choices such as flexible grading, assignment options or selfdetermined due dates.

- Students can be given consistent, credible and specific encouragement such as "You can do this."

- Praise and encouragement to students is very important. When giving feedback on student performance, compare to past performances by the same student and do not make comparisons between students.

- Making the students understand that they fail because they did not follow instructions and they did not spend enough time on the task.

\section{CONCLUSIONS}

The present students are the future generation of our nation and the development of our country rests in their hands. To make our nation proud among other countries, it is imperative to train the students to excel in all the fields especially in the development of science and technology. Country's development is measured on technological advancement and it is the duty of teachers, parents and educational authorities to prepare the students to face the challenges in the future. It may be helpful if the higher education authorities and curriculum developers make shift in their curriculum so that they can instill motivation to learn Mathematics among the students and increase their Self-efficacy to achieve better. Also, it is important that our Higher Secondary education department can address some of the practical issues faced by the students and teachers and prepare the future mathematicians with increased higher order thinking and performance skills.

\section{REFERENCES}

1. Logical reasoning ability and student performance in general chemistry

2. Ayotola, A., \&Adedeji, T. (2009). The relationship between mathematics self-efficacy and achievement in Mathematics. Procedia Social and Behavioral Sciences, 1(1), 953-957. Bandura, A. (1977). Self-Efficacy: Towards a unifying theory of behavioral change. Psychological Review, 84, 191-215.

3. Bandura, A. (1997). Self-efficacy: The exercise of self-control. New York: W.H. Freeman and Company. 
4. Brown, S.D. \& Lent, R.W. (2006). Preparing adolescents to make career decisions: A social cognitive perspective. In F. Pajares \& T. Urdan (2006). Adolescence and Education: Vol.5 Self-efficacy beliefs of adolescents (pp.201-223). Greenwich, CT: Information age.

5. Fennema , E. (1989). The study of affect and mathematics: A proposed generic model for research. In D.B. Mcleod \& V.M. Adams (Eds.), Affect and Mathematical Problem Solving: A new perspective. (pp. 207-219). London: Springer-Verlag.

6. Ara, Talat., \& Choudhary, A. K. (2014). Study on efficacy of two strains (ATCC 15834 and MTCC 532) of Agrobacterium rhizogenes on hairy root induction of Withania somnifera. Int J Biotechnol Res, 4, 1-8.

7. Huitt, W. (1996). The mind. Educational Psychology Interactive. Valdosta, GA: Valdosta State University. Retrieved from http://chiron.valdosta.edu/whuitt/champion/mind.html

8. Laganfield, T.E., \&Pajares, F. (1993). The mathematics self-efficacy scale: A validation study. Paper presented at the Annual Meeting of the American Educational Research Association.

9. Pajares, F. (1996). Self Efficacy beliefs in mathematical problem solving of gifted students. Contemporary Educational Psychology, 21, 325-344.

10. Pajares, F., \&Kranzler, J. (1995). Self-efficacy beliefs and general mental ability in mathematical problem solving. Contemporary Educational Psychology, 20, 426-443.

11. Tait, S.L. \& McCutcheon (2008). Self-Efficacy in Mathematics: Affective, Cognitive and Conative Domains of Functioning, Proceedings of the 31st Annual Conference of the Mathematics Education Research Group of Australasia, MERGA Inc.

12. Soumya, M., \& Abraham, A. Optimisation of Light Dose and Preliminary Studies on the Efficacy of Symmetrical Diiodinated Squaraine for PDT Applications on Skin Tumor Induced Models.

13. Tallon (1997). Head and Heart: Affection, Cognition, Volition as triune consciousness. New York: Fordham University.

14. Tanner, H. \& Jones, S. (2003). Self-efficacy in mathematics and students' use of self-regulated learning strategies during assessment events. In N.A. Pateman, B.J. Dougherty, \&J.T. Zilliox, Proceedings of the 27th Conference of the International Group for the Psychology of Mathematics Education (PME27), pp.275-82, Honolulu, HI. 